\title{
Muallim Orhan Fuad Tarafından İlk Mekteplerin 5. Sınıfları İçin Yazılan “Musâhabât-1 Ahlâkiye ve Malûmât-ı Vataniye" Adlı Ders Kitabının Değerlendirilmesi
}

Evaluation of the Textbook "Musâhabât-ı Ahlâkiye ve Malûmât-ı Vataniye" written by Muallim Orhan Fuad for the 5th Grades of Primary Schools

Muhammet Demirkaya

Öğretmen

Milli Eğitim Bakanlığ1

muhammetdemirkaya@gmail.com

ORCID ID: 0000-0002-5494-4264
Selim Selimoğlu

Doktora Öğrencisi

Afyon Kocatepe Üniversitesi sselimoglu07@gmail.com

ORCID ID: 0000-0001-6109-7043
Ahmet Ali Gazel

Prof. Dr.

Afyon Kocatepe Üniversitesi agazel@aku.edu.tr

ORCID ID: 0000-0002-7211-6032

\section{Makale Bilgisi / Article Information}

Makale Türü / Article Type : Araştırma Makalesi

Geliş Tarihi / Received : 29 Kasım 2021

Kabul Tarihi / Accepted : 12 Aralık 2021

Yayın Tarihi / Published : 15 Aralık 2021

DOI Number : 10.20860/ijoses.1030035

Bu makale Prof. Dr. Ahmet Ali Gazel'in danışmanlığında Muhammet Demirkaya'nın Afyon Kocatepe Üniversitesi Sosyal Bilimler Enstitüsü'nde hazırladığı, makale ile aynı başlıklı tezden üretilmiştir.

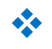

\section{Kaynak Gösterme / Citation}

Demirel, F. "Muallim Orhan Fuad Tarafindan İlk Mekteplerin 5. Sınıfları İçin Yazılan "Musâhabât-1 Ahlâkiye ve Malûmât-1 Vataniye"Adlı Ders Kitabının Değerlendirilmesi". Uluslararası Sosyal ve Eğitim Bilimleri Dergisi, 16 (2021): 275-290. 


\title{
Muallim Orhan Fuad Tarafından İlk Mekteplerin 5. Sınıfları İçin Yazılan "Musâhabât-1 Ahlâkiye ve Malûmât-ı Vataniye" Adlı Ders Kitabının Değerlendirilmesi
}

\author{
Evaluation of the Textbook "Musâhabât-ı Ahlâkiye ve Malûmât-ı Vataniye" written by Muallim \\ Orhan Fuad for the 5th Grades of Primary Schools
}

\section{Muhammet Demirkaya \& Selim Selimoğlu \& Ahmet Ali Gazel}

$\ddot{O} z$

Bu çalışmanın amacı, 1924 yıında Muallim Orhan Fuad tarafından ilk mekteplerin 5. sınıflarında okutulmak üzere yazılan "Musâhabât-ı Ahlâkiye ve Malûmât-ı Vataniye 5" adlı ders kitaplarını farklı açılardan değerlendirmektir. Bu amaç doğrultusunda "Musâhabât-ı Ahlâkiye ve Malûmât-ı Vataniye 5" kitapları öncelikle konu konu çözümlenmiştir. Diğer yandan konularla ilgili çeşitli açılardan yorumlar yapılmıştır. Çalışma, nitel türde olup doküman analizi yöntemiyle yürütülmüştür. Çalışmanın bulguları arasında vatan kavramının nasıl ele alındığı, hükümetin kurulma gerekçeleri, Cumhuriyet rejiminin üstünlükleri, bireylerin sahip oldukları hak ve sorumluluklar yer almaktadır. Çalışmanın sonucunda "Musâhabât-ı Ahlâkiye ve Malûmât-ı Vataniye 5" kitaplarının; 1924 Illk Mektep Müfredat Programı'na genel anlamda uygun olduğu, metinlerin biçim ve içerik yönüyle kolaydan zora doğru sıralandığı, hedef kitlenin becerisini geliştirecek nitelikte olduğu ve Cumhuriyetin kurguladığı toplumun özelliklerini yansıttığı söylenebilir.

Anahtar Kelimeler: Vatandaşlık bilgisi, Ahlak bilgisi, Muallim Orhan Fuad.

\section{Abstract}

The aim of this study is to evaluate the textbooks named "Musâhabât-ı Ahlâkiye ve Malûmât-ı Vataniye 5", written by Muallim Orhan Fuad in 1924 to be taught in the 5th grades of primary schools, from different perspectives. For this purpose, the books "Musâhabât-ı Ahlâkiye ve Malûmât-ı Vataniye 5" were firstly analyzed subject by subject. On the other hand, comments have been made on the issues from various angles. The study is of qualitative type and was carried out by document analysis method. Among the findings of the study are how the concept of homeland is handled, the reasons for the establishment of the government, the advantages of the republican regime, the rights and responsibilities of individuals. As a result of the study, "Musahabat-ı Ahlakiye ve Malumat-I Vataniye 5" books; It can be said that it is generally suitable for the 1924 Primary School Curriculum, the texts are arranged from easy to difficult in terms of form and content, they have the quality to improve the skills of the target audience and reflect the characteristics of the society that the Republic built.

Keywords: Citizenship knowledge, Moral knowledge, Teacher Orhan Fuad. 


\section{Extended Summary}

\section{Purpose and Significance:}

Republican period political, social, cultural and economic etc. has necessitated change and transformation in many areas. The main purpose of the republican regime can be thought of as ensuring the future of the order, as well as making the generations of the republic adopt the core values, semantic world and beliefs of the social and political order through a reconstructed education system (Parlak, 2005: 91). Especially in periods when regime problems cause sensitivity, school gains great importance as a tool to create an ideology. Textbooks, educational methods, and teachers' attitudes are followed with great interest and directed by the political power (Alkan, 1979: 93). In this sense, the citizenship textbooks of the early Republican period played a very important role in the acceptance of the Republican regime.

During the Early Republic period, two important program changes were made that affected citizenship education. The first of these is the First School Curriculum of 1924. The program in question has the feature of being the first program of the National Education of the Republic of Turkey (Keskin, 2002: 26).

The rights and responsibilities of the individual in the early republican period were tried to be conveyed through moral and citizenship textbooks. Ethics and Citizenship lessons expressed the necessity of not only the rights of the individual but also the duties of the individual within the framework of citizenship. Because the citizenship of the Republic is based not only on a human being defined by his rights, but also on a human design with obligations (Gürses, 2001:33-34). In fact, duties and responsibilities come before rights. Here, morality and citizenship courses are the field in which these rights and responsibilities are framed and offered to individuals at a certain program and level, and morality courses directly serve these responsibilities and obligations.

Citizenship in Turkey emerged as a part of the modernization project, shaped around the ideas of Ottomanism, Islamism, Turkism and later Westernism in the 19th century Ottoman period (Gürses, 2001: 368). Especially the change and transformation in the field of law necessitated the redefinition of the individual. In the textbooks of the period, it was stated that the individual was equal before the law and that compliance with the laws was essential. The aim of this study; The aim of this study is to analyze and evaluate the citizenship textbook named "Musahabat-1 Ahlakiye ve Malumat-1 Vataniye 5", which was written by Muallim Orhan Fuad in 1924 to be taught in the 5th grades of primary schools.

\section{Methodology:}

In this study, the document analysis method, which is one of the qualitative research approaches, was used. Document analysis includes the analysis of written materials containing information about the facts and cases that are aimed to be investigated. In addition, documents are important sources of information that should be used effectively in qualitative research, and therefore, the data required in such research can be obtained without the need for observation and interview (Y1ldırım and Şimşek, 2011: 187-188). For this purpose, the moral and citizenship textbooks of the Republican era were analyzed using the document analysis method.

\section{Results, discussion and conclusion:}

The aim of this study; The aim of this study is to analyze and evaluate the citizenship textbook named "Musahabat-1 Ahlakiye ve Malumat-1 Vataniye 5", which was written by Muallim Orhan Fuad in 1924 to be taught in the 5th grades of primary schools. The author of the book "Musahabat-1 Ahlakiye ve Malumat-1 Vataniye 5" is Muallim Orhan Fuad. The book in question was prepared to be 
taught in accordance with the curriculum of the primary schools in 1340 (1924) of the Ministry of Education of the Republic of Turkey. The book is a civics textbook for fifth grade primary schools. The points emphasized in the textbook named Musahabat-1 Ahlakiye ve Malumat-1 Vataniye 5' are as follows. The concept of homeland has been discussed in the context of borders, perhaps because the borders of the state were newly determined. As the reason for the establishment of the government, it has been argued that first of all, the person is alone in nature, then he establishes a family and becomes a community, and that a government should be established in order to manage this growing social structure. It is tried to glorify the republican regime by expressing how many rights individuals are deprived of in states where there is no republic. Such reminders are repeated over and over on many subjects until the idea that the republican regime is the best form of government awakens in the child's mind. It is quite natural for such expressions to be in all textbooks so that ideology can flourish and grow. Because every newly established institution comes to terms with the old one. Everyone is equal before the law and no one has the luxury of not agreeing with the law. In this case, an individual's neck is thinner than a hair before the law.

As a result, the topics covered in the 5th grade citizenship textbook focus on the establishment of the state in general and then touch on the rights that the regime brought to the people. First of all, the reasons for the establishment of the state in a homeland with certain borders and the formation of a government to manage this state are presented. Regarding the necessity of the government, it is explained that such a structure becomes necessary as one goes from the smallest community structure to the largest. On the other hand, it is mentioned that the fact that the regime of the established state is a republic will provide individuals living under the roof of the said state with many rights and benefits that are not available in other regimes. In this case, it can be said that individuals are tried to be convinced that the Republic is the best regime and to make them think in this direction. Because while there are many eulogies about the regime in most parts of the book, other regimes are introduced as extremely unnecessary and bad.

\section{Giriş}

Cumhuriyet dönemi siyasi, sosyal, kültürel ve ekonomik vb. birçok alanda değişim ve dönüşümü gerekli kılmıştır. Cumhuriyet rejiminin temel amacı, yeniden kurgulanmış bir eğitim sistemi aracılığıyla Cumhuriyet nesillerine toplumsal ve siyasal düzenin öz değerlerini, anlam dünyasını ve inançlarını benimsetmenin yanı sıra düzenin geleceğini de garanti altına almak olarak düşünülebilir (Parlak, 2005: 91). Özellikle rejim sorunlarının duyarlılığa neden olduğu dönemlerde, bir ideoloji oluşturma aracı olarak okul büyük önem kazanıyor. Ders kitapları, eğitim yöntemleri, öğretmenlerin tutumları siyasal iktidar tarafından büyük bir ilgiyle izleniyor ve yönlendiriliyor (Alkan, 1979:93). Bu anlamda erken Cumhuriyet dönemi vatandaşlık ders kitapları Cumhuriyet rejiminin kabul görmesinde oldukça önemli bir rol üstlenmiştir. Hükümetin kurulmasından, devletin tesis sürecine ve hükümetin kurulma gerekçelerinin temellendirilmesi dönemin ders kitapları aracılığıyla yapılmaya çalışılmıştır. İttihat ve Terakki yönetimi, öncelikle eski rejimi ve onun sembolü haline gelmiş olan II. Abdülhamit'i övücü, yüceltici ifadeleri ders kitaplarından çıkarmıştır. Yerine, bir taraftan yeni rejim (meşrutiyet)i öven, yücelten ifadeler yerleştirmiş bir taraftan da II. Abdülhamit ve yönetim şeklini şiddetle eleştirmiştir. Bu noktada, Meşrutiyet idaresinin, eski (Mutlakıyet) rejime oranla daha müdahaleci olduğu söylenebilir. Çünkü yeni rejim, meşrutiyet problemi ile yüz yüzedir (Doğan,1994:70). Cumhuriyet dönemi vatandaşlık ders kitapları meşrutiyet problemini aşmada benzer görevini devam ettirmiştir. Mutlakıyet ve 2. Meşrutiyet dönemi ders kitapları karşılıklı incelendiğinde dini öğelerin ders kitaplarında yer alması ise padişahı öven ifadelerin de yer aldığı görülmüştür. Dini öğeler ders kitabının dışına itildikçe ders 
kitaplarından padişah ve saltanat öğelerinin de çıkarıldığı ortaya çıkmaktadır. II. Abdülhamit dönemi ahlak kitapları ahlak eğitimini verirken dinî içerikli bir uygulama yaparken, aynı şekilde padişaha itaat, sevgi ve saygılar dini bir misyonda gerçekleştirilirken, II. Meşrutiyet ve Erken cumhuriyette ahlakın, mevcut yönetimin dayanak noktası bilim olmuştur (Doğan, 1994: 71).

Erken Cumhuriyet döneminde vatandaşlık eğitimini etkileyen iki önemli program değişikliği gerçekleşmiş̧ir. Bunlardan ilki 1924 tarihli İlk Mektep Müfredat Programı'dır. Söz konusu program, Türkiye Cumhuriyeti Millî Eğitimi’nin ilk programı olma özelliğini taşımaktadır (Keskin, 2002: 26). Ara program niteliği gösteren bu program ile 11 senedir devam eden üç devreli ve 6 yıllık ilkokullar kaldırılarak yerlerine 5 senelik ilkokullar konulmuştur. $\mathrm{Bu}$ program vatandaşlık eğitimi ile doğrudan ilgili olan Tarih, Coğrafya ve Musahabat-1 Ahlakiye ve Malumat-1 Vataniye derslerini içermektedir. Tarih ve Coğrafya dersleri 3. sınıfta birer saat, 4. ve 5. sınıflarda ikişer saat iken, Musâhabât-1 Ahlâkiye ve Malâmât-1 Vataniye dersi her sınıfta birer saat olarak verilmiştir (İlk Mektepler Müfredat Program1, 1924: 3). Musahabat-1 Ahlakiye ve Malumat-1 Vataniye dersinin amac1 programda şu şekilde belirtilmiştir: "Musahabat-1 Ahlakiye ve Malumat-1 Vataniye derslerinin gayesi gençlere Türkiye Cumhuriyeti'nin bir vatandaşı olmak sıfatıyla malik oldukları hak ve vazifelerini tanıtmak, bütün hareketlerinde hâkim olması lazım gelen ahlak esaslarını telkin etmek, ve'l-hâsıl milli ve insani vazifelerini takdir ve ifa edebilecek bir hale getirmektir" (IMMP, 1924: 29). Buna amaca göre söz konusu dönem vatandaşlık eğitiminde hak ve sorumluluk bilinci taşımanın yanı sıra ahlak eğitimine de önem verildiği söylenebilir (Çelik, 2008: 363). Yurttaşlık bilgisi, genel olarak ahlak eğitiminin bir parçası olarak görülmüş ve yurttaşın fert olarak ülkesine karşı vazifeleri öğretilmeye çalışılmıştır (Karakuş, 2018: 165).

Erken cumhuriyet dönemi bireyin hak ve sorumlulukları ahlak ve vatandaşlık ders kitapları üzerinden aktarılmaya çalışılmıştır. Ahlak ve Yurttaşlık dersleri sadece bireyin haklarının değil vazifelerinin gerekliliğini de vatandaşlık çerçevesinde ifade etmiştir. Çünkü Cumhuriyet yurttaşlığı, sadece haklarıyla tanımlanan bir insan değil, yükümlülükleri de bulunan bir insan tasarımında dayanır (Gürses, 2001: 33-34). Hatta vazife ve sorumluluklar haklardan önce gelmektedir. İşte bu hak ve sorumlulukların çerçevesinin çizildiği, belli bir programda ve düzeyde bireylere sunulduğu alan ahlak ve yurttaşlık dersleridir ki ahlak dersleri bu sorumluluk ve yükümlülere direkt hizmet etmektedir.

Türkiye'de vatandaşlık, 19. yüzyıl Osmanlı dönemindeki Osmanlıcılık, İslamcılık, Türkçülük ve sonrasında eklenen Batıcılık fikirleri etrafında biçimlenmiş, modernleşme projesinin parçası olarak ortaya çıkmıştır (Gürses, 2001: 368). Özellikle hukuk alanındaki değişim ve dönüşüm bireyin yeniden tanımlanmasını gerekli kılmıştır. Dönemin ders kitaplarında bireyin kanun önünde eşit olduğu ve kanunlara uyumun esas olduğu belirtilmiştir. $\mathrm{Bu}$ çalışmanın amacı; 1924 yılında Muallim Orhan Fuad tarafından ilk mekteblerin 5. sınıflarında tedrîs edilmek üzere" yazılan "Musâhabât-ı Ahlâkiye ve Malâmât-ı Vataniye 5" adlı vatandaşlık ders kitabını çözümlemek ve çeşitli açılardan değerlendirmektir. 


\section{Yöntem}

$\mathrm{Bu}$ çalışmada nitel araştırma yaklaşımlarından olan doküman analizi yöntemi kullanılmıştır. Doküman incelemesi, araştırılması hedeflenen olgu ve olgular hakkında bilgi içeren yazılı materyallerin analizini kapsar. Ayrıca dokümanlar, nitel araştırmalarda etkili bir şekilde kullanılması gereken önemli bilgi kaynaklarıdır ve bundan dolayı bu tür araştırmalarda gerekli olan veriyi gözlem ve görüşme yapmaya gerek kalmadan elde edilebilir (Yıldırım ve Şimşek, 2011: 187-188). Bu amaçla Cumhuriyet dönemi ahlak ve vatandaşlık ders kitapları doküman analizi yöntemi kullanılarak analiz edilmiştir.

\section{Örneklem}

Araştırmanın örneklemi amaçlı örnekleme yöntemi ile belirlenmiştir. 1924 yılında Muallim Orhan Fuad tarafından ilk mektepler için kaleme alınan "Musâhabât-ı Ahlâkiye ve Malûmât-ı Vataniye 5" adlı eski harfli ders kitabı araştırmanın örneklemini oluşturmaktadır.

\section{Verilerin Analizi}

Verilerin çözümlenmesinde öncelikle transkripsiyon yapılmış daha sonra betimsel analiz yöntemi kullanılmıştır. Betimsel analize göre, elde edilen veriler, daha önceden belirlenen temalara göre özetlenip yorumlanır. Betimsel analizde gözlenen ya da görüşülen bireylerin görüşlerini daha çarpıcı bir biçimde yansıtmak amacıyla doğrudan alıntılara sık sık yer verilir (Y1ldırım ve Şimşek, 2011: 224).

\section{Bulgular ve Yorumlar}

\section{Kitabın Künye Bilgileri}

Kitabın tam adı Musahabat-1 Ahlakiye ve Malumat-1 Vataniye 5'tir. Kitabın yazarı Muallim Orhan Fuad olup kitap, Türkiye Cumhuriyeti Maarif Vekâletinin 1340 (1924) senesi ilk mektepler müfredat programına göre tedris edilmek üzere kabul edilmiştir. Söz konusu kitap İlk Mektepler beşinci sınıfına mahsus bir Vatandaşlık Bilgisi ders kitabıdır. Kitap İstabul Akdam matbaasında 1924 tarihinde basılmıştır.

\section{Eserin İncelenmesi ve Değerlendirilmesi}

Kitap toplam 4 kısım 15 konudan oluşmaktadır. Birinci kısım 5 konu, ikinci kısım 3 konu, üçüncü kısım 3 konu, son olarak dördüncü kısım 4 konudan oluşmaktadır.

Birinci kısım öğrencilere genel bir vatan, vatandaş- millet- millettaş bilinci edindirmeyi hedeflemektedir. Konular olarak, vatan, millet, hükümet, devlet, hükümetin şekilleri, milli hakimiyet, meşruti hükümet ve cumhuriyet, cumhuriyet neden en iyi hükümet şeklidir, cumhuriyetin halka sağladığı faydalar, halkın ve milli istiklalin düşmanları şeklindedir. $\mathrm{Bu}$ konuların beş derste, beş haftada işlenmesi öngörülmüştür.

Birinci kısmın birinci konusu vatan bilgisine ilişkin olup, millet, hükümet ve devlet kavramlarına değinilmiş olup hükümet ve muhtelif şekiller üzerinde de durulmuştur. Öncelikle vatan kavramının tanımı yapılmıştır.

Vatan denildiği zaman insanın en evvel hatırına kendisinin doğup büyüdüğü yer gelir. Hâlbuki: bu düşünüş tamamıyla doğru değildir (s: 7). 
Yazar bu tanımı şu örneklendirmeyle tamamlamıştır: "Ben halis Türk olduğum halde ailemin bulunduğu Bağdat, Halep veya Marsilya' da doğsam da oralar vatanım değildir. Onlar farklı 1rk ve milletlere mensuptur. Ben oranın vatandaşı olamam. Fakat Erzincan'da doğmuş olsam burası benim vatanım olur. Çünkü bağlı olduğum Türkiye Cumhuriyeti’nin idaresi altındadır. Halkının tamamı benim gibi Türk’tür. Benim Erzincan belediyesine meclis idaresine ve hatta Büyük Millet Meclisine hem temsilci seçmeye hem de seçilmeye hakkım vardır. Ben ve Erzincanlılar millet ve devletimiz hakkında aynı şeyi düşünürüz. Orası benim vatanımdır."

Burada yazar devletin sınırlarının yeni oluşmuş olduğundan dolayıdır ki, vatan kavramını sınırlar bağlamında ele almıştır. Dönem atmosferinde bu tanım gayet normal olarak karşılanabilir. Savaştan çıkan bir milletin vatan tanımında sınırın ağırlıklı olması gayet doğal bir durumdur.

Yazar bu bölümü vatan ve vatandaşları sevip onlara karşı fedakar olmalı, vatan uğrunda can veren şehitlerimizi asla unutmamal1, onların evlat ve ailelerine elden gelen yardım esirgenememelidir şeklinde tavsiyelerde bulunmuştur. Dünyanın her köşesindeki, bütün insanların bir vatan kaygısı vardır, vatansız bir millet olamaz ve milletler ilim ve medeniyette ilerledikçe umumi vatanlarına karşı ilgileri de o denli artar.

Birinci kısmın ikinci konusu millet ve hükümet kavramlarına odaklanmaktadır. İlk olarak vatandaş ve millettaşın aynı anlama gelmediğini vurgular mahiyette şu ifadeleri kullanmıştır: "Vatandaş aynı siyasi sınırlar içinde doğup yaşayan, aynı hükümet ve aynı kanunlara tabi bulunan kimselerdir. Ki bunların dil ve dinlerinin bir olması şart değildir. Türkiye halkından bir Türk aynı halktan bir Yahudi ile vatandaştır fakat millettaş değildir. Millettaşların ise aynı siyasi sınırlar içinde doğup yaşaması ve aynı hükümete tabi olması gerekmez, bunlar ırk, dil, kültür ve tarihi gelenek olarak birbirine bağlı kişilerdir. Ermeniler ve Araplar gibi Türkler de başlı başına büyük bir millettir." Yazar burada birinci konudaki sınırları biraz daha esnetmiş ve bütün Türk milletinin fertlerinin de millet kavramı bağlamında değerlendirilebileceğini ileri sürmüştür. Aşağıdaki ifadelerde bu görüş teyit edilmektedir.

Bununla beraber başka hudutlar dâhilinde kalmış olan başka Türkleri de severiz; onların menfaat ve sadetlerini isteriz, düşünürüz; onlar harici bir düşmanın tecavüzüne uğrasalar biz burada kederleriniz; çünkü onlarda bizim kan, lisan, din kardeşlerimizdir (s:14).

Yukarıdaki ifadeler Cumhuriyet bireylerinin vatan sınırları dışındaki Türk insanını da tanıması, bilmesi ve ilişki içerisinde olması gerektiğini göstermektedir.

Bu bölümde ikinci bir kavram olarak hükümet dile getirilmiştir. Hükümetin gerekliliği anlamında bir alt yapı oluşturmak adına tabiattan bir örnek sunulmuştur.

Malumdur ki insan: insan kuvvetçe, çeviklikçe hayvanların birçoğundan geridir. Yalnız başına kalırsa hiç bir hayvana karşı gelemez. Onunla başa çıkamaz. İnsanın kedi kadar olsun keskin tırnağı, at kadar kuvvetli bacağı, kur gibi sivri dişleri, aslan kaplan gibi yırtıcı pençesi olmadığı gibi ceylan ve tavşan kadar kaçmak, koşmak gibi uçmak hassası da yoktur (s: 14).

Diğer yandan hükümet kurmanın temeli olarak aile kavramına da değinilmiştir.

İnsanoğulları henüz mağara hayatı yaşarken bile aile teşkil etmişlerdir. $\mathrm{Bu}$ aileler, kendilerini yırtıcı hayvanlardan korumak için bir kaçı bir arada cemiyet halinde yaşamaya mecbur olmuşlardır (s: 15). 
Hükümet kurmanın en temel gerekçeleri bağlamında yazar şu ifadeleri kullanmıştır.

Başkalarının hakkını el uzatanları durdurabilecek, onlara ceza verecek, gece hırsızlıklarını men edecek, çocukların haylaz kalmaması için mektepler açacak. Bir kuvvete ihtiyaç olduğunu anlamışlar (s: 15).

$\mathrm{Bu}$ bölümde yazar, çocukların zihinlerinde hükümet kavramını canlandırma adına basitten karmaşığa, küçükten büyüğe doğru hükümetin neden gerekli olduğu fikrini onlara aşılamaya çalışmıştır. Öncelikle kişinin tabiat içinde yalnız olduğu, daha sonra aile kurduğu ve cemaatleştiği ve büyüyen bu toplum yapısını idare etmek için hükümetin kurulması gerektiğini belirtmiştir. Özet olarak;

İşte buraya kadar verdiğimiz malumattan hulasa olarak şu anlaş1lır ki: milli ve siyasi hudut dâhilinde oturan her adam bir vatandaş veya bir millettaştır. Bunların mecmu'u yani cemaati ve bunların işlerini gören ve yine kendi aralarından ayrılıp tayin kılınan kimselerin, [memurlar] mecmuu da [hükümet]i teşkil eder (s: 17).

Birinci kısmın son konusunda yazar devlet, vatan, hükümet ve hükümetin muhtelif şekillerine değinmiştir. Yazar konuya kavramsal analizle başlamış ve şöyle bir tespitte bulunmuştur. Genellikle devlet, millet ve hükümet kelimeleri birbiriyle karıştırılır. Bunların farklı anlamları vardır. Millet, idare olunan topluluk, hükümet idare eden teşkilattır. Hükümet milletten ayrı olmamakla birlikte görev itibariyle ondan ayrılır. Milletin her ferdi ehil ise hükümet heyeti arasına girebilir. Memuriyetten ayrıldığında millet ferdi olur. Dolayısıyla görevli maaş̧ı memurların tamamı hükümeti, dışta kalıp kendi iş ve gücüyle uğraşan halk da milleti oluşturur. Sadece görev konusunda birbirinden ayrılan ve fakat ne birbirinin aynı ne de gayri olan bu iki kavramı birleştirmek için devlet kelimesi kullanılır.

Bir devlet misali:

Şimdi küçük efemdiler, şu üç derste size söylediklerimiz şeyleri küçük bir misal ile daha ziyade izah edelim ve mesela: bugün içinde okumakta olduğunuz sevimli mektebinizi el alalım:

Mektebinizde neler var? Evvela bir mektep binası görüyoruz. Bunun bahçesi, dershaneleri, salonları, kütüphanesi, dehlizleri, yemekhaneleri var. Bunun etrafı bir duvar ile çevrilerek başkalarının mülkünden ayrılmıştır. Bahçedeki havuz, kuyu, çeşme, hatta ağaçlar bile mektebin bir cüz'üdür.

İşte size bir [Vatan] numunesi:

Bu mektepte daha neler görüyorsunuz.? İkinci derecede bir çok adamlar: kapıcı, hademe, talebe, muayyid, muallimler, müdür ve muavini ve kâtip vesaire. İște size bir [millet] numunesi:

Fakat görüyoruz ki, bu adamların hepsinin vazifesi bir değil. Talebenin vazifesi sadece okumak, mektebin nizamlarına itaat, muallimlere, müdüre hürmet etmektir.

Talebenin dışında kalanların vazifesi ise, çocukları okutmak, onlara güzel ahlakı, malumatlı birer adam olarak yetiştirmek, mektebin ileri gitmesi için konmuş olan nizamları tatbik ve icra etmek vel-hâsıl mektep içinde intizamı muhafaza eylemektir. 
Görülüyor ki, talebe ile idare ve talim işleriyle uğraşanların hep bir cinsten, bir milletten. Aralarında ayrılık gayrilik yoktur. Belki yarın mektepten şahadetname alan talebeden bir kaçı bu mektebe muayyid ve muallim olabilir. Çünkü bunun hakkıdır.

İşte bu idare ve talim ve inzibat işleriyle uğraşanlarda o [vatan] ve [millet] e göre: bir [hükümet] numunesidir.

Fakat biz istiyoruz ki, mektebimizin bütün mevcudiyetini bir veya birkaç kelime ile ifade edelim; onu başka mekteplerden ayırt edelim.

O zaman ne yaparız? Yalnız mektebimizin ismini söylemek maksadı temin eder. Mesela: Cumhuriyet Mektebi. !

İște biz bu tabirle mektebin konumunu veya binasını bahçesini sıra ve tahtalarını kapıcısını, hademesini, talebesini, muayyid ve muallim, katib, muavin ve müdürünü kast etmiş oluyoruz ki bununla bir devlet örneği meydana gelmiş bulunuyor (s: 19-20).

Bu konuda devlet kavramı işlenmesine rağmen bu kavrama ilişkin tanımlama net ve açık değildir. Sadece basit bir örneklendirmeyle yetinilmiştir. Bu durumun sebebi olarak öğrencilerin fikri ve zihni hazırbulunuşluk düzeylerinin yeterli olmaması olarak düşünülebilir. Sonuç olarak devlet kavramı daha soyut özelliklere sahip olduğu için bu yaştaki çocukların anlamaları da o derece zor olduğu söylenebilir. Yazar dipnot olarak da olsa önemli bir konuya temas etmiştir. Bir adama Türkiye tebaasından demek yanlıştır o, Türkiye devletinin tebaasidir.

Yazar son bölümde bir netice mahiyetinde önerdiği ve övdüğü Cumhuriyet ve Meşrutiyet idarelerinin düşmanlarını doğal olarak da mutlakıyet idaresinin dostlarını şu şekilde sıralayarak bölümü sonlandırmıştır.

Acaba bunlar kimlerdir?

Hükümdarlar ve bunların hanedanına yakından, uzaktan garabet ve münasebeti olanlar.

Hiçbir hak ve liyakatleri olmadığı halde mahza hükümdarlara çatarak gayri meşru menfaatlerini elde etmeye alışan veya elde etmeyi isteyen saray adamları, devlet düşkünleri.

Ehliyetsizliklerden dolayı veya hükmet dairelerinde yer bulamayan kimseler.

Ecnebi himaye ve muhabbetini taşıyan şahıslar.

Din perdesi altına gizlenip halkı soymayı adet edinen bazı sahtekârlar ile cahil ve mutaassiplar.

Terakki ve teceddüdü kafalarına sığdıramayanlar.

İşte bunlar, Cumhuriyet idaresinden değil hatta hükümet-i meşrutadan bile memnun değildirler ve olamazlar. Bunların eline ufak bir firsat geçse hemen hükümet-i mutlakayı yeniden kurmak isterler (s: 27).

Bu konuda ideolojik sempatinin sonucu olan bir ayrıştırma yapılmıştır. Altta yatan temel mesaj, modern bireylerin özellikle Cumhuriyet ve meşrutiyet rejimlerine sahip çıkmaları gerektiğidir 
Kitabın ikinci kısmı üç konudan oluşmaktadır. Bu konular Milli Mücadele dönemine ilişkin bilgiler içermektedir. Genel olarak, İstiklâl mücadelesinin tarihçesi, Türkiye Büyük Millet Meclisi'nin teşekkülü, Türkiye Cumhuriyeti'nin ilanı ve bundan görünen faydalara yönelik konulardan bahsedilmektedir.

İstiklâl mücadelesinin tarihçesi konusunda I. Dünya savaşının genel anlamda savaşın çıkış nedenlerine ve sürece odaklanılmıştır. Genel anlamda o dönemde devletin zayıf ve çaresiz düştüğünden bahsedilmiştir.

İngilizler ve Fransızlar sözlerinde durmadılar. Askerimizin dağıldı̆̆ını, silahlarımızın teslim olunduğunu, boğazların açıldığını firsat bilerek, hiçbir münasebet yok iken İstanbul'a, İzmit'e, İzmir'e, Adana'ya birçok asker çıkardılar. Tabi elde kuvvetimiz olmadığı için bunlara karşı koyamadık; boynumuzu büküp seyirci kaldık (s: 30 ).

Diğer yandan İstiklal mücadelesi sonrasında kazanılan zaferlere ilişkin Sultan Vahdettin hakkında çeşitli ifadeler kullanılmıştır.

$\mathrm{Bu}$ hamiyetsiz padişah, milli Türk ordusunun nail olduğu zaferi çekemedi. Belki İngilizlerden, Yunanlardan ziyade me'yüs aldı. Nihayet akıbetini düşünerek beş on gün sonra avenesinden bir kaçını birlikte alarak şafak vakti Yıldız Sarayının arka kapısından çıtı. Kendisini orada bekleyen İngiliz generaline - utanmadan teslim etti. İngiliz muhafizlarının himayesi altında bir İngiliz harp sefinesine (gemisine) binerek defolup gitti. Bunun firarıyla artık memleketimizde padişahlık devrine hitam verildi (s: 38 ).

Yeni bir rejim kurma aşamasında eskileri kötülemek, aşağılamak ve yok etmek için elden gelen ne varsa yapılmaya çalışılır. Yukarıdaki alıntıda yazar bu durumun gereğini yapmış ve eskiye yönelik sert eleştirilerini dile getirmiştir.

Cumhuriyetin ilanı konusunda ise yüceltmelerle dolu bir bölüm hazırlanmıştır. Bu konuda yine eskiye yönelik sert eleştiriler sürdürülmüştür.

Osmanlı imparatorluğunun son Sultanı olan [hain sultan] [Mehmet Vahdettin] ni milli ordumuzun kazandığ 1 zafer üzerine korkusundan İngilizlere iltica ederek İstanbul'dan firarından sonra artık memleketimizde resmen imparatorluğa, hükümdarlığa katiyen hitam verildi.

Halk altı yüz seneden beri padişahların keyfi idarelerinden, israflarından, zulüm ve istibdatlarından o derece bıkıp usanmış idi ki: [padişah] [sultan] denildi mi herkesin tüyleri ürperiyordu.

Binaen aleyh bundan böyle tekrar bir padişahın boyunduruğu altına girmeyi, bir hanedanın yükünü sırtında taşımayı istemezdi.

Birkaçı müstesna olmak üzere bütün medeni milletlerde, birer birer hükümdarlarını, baş belalarını kovup yerine Cumhuriyet idaresini kurmamışlar mı? Biz niçin onlardan geri kalalım? (s: 40)

Yukarıdaki alıntıda yine medeni devletler ön plana alınarak o devletler gibi olunması gerektiği savunulmaktadır. Hükümdarın bir baş belası olarak görülmesi ve onun kovularak yerine Cumhuriyet rejiminin kurulması yine eski yeni karşıtlıklarını gözler önüne sermektedir. Yazar Cumhuriyet idaresinin sadece medeni devletlerde olduğunu ve Türkiye'nin de o medeni 
devletler seviyesine ulaşmak için mutlaka Cumhuriyet rejiminin kurulması gerektiğini belirtmiştir.

[Cumhuriyet] ilan etmekle artık hakiki meşrutiyete nail olduk demektir. Bir kere hükümdar korkusundan sonra onların bir sürü faydasız ailesi efradını milyonca liralar sarf ederek beslemekten kurtulduk.

Hükümetimizin şseklini Cumhuriyete kalp etmekle bütün Avrupa nazarında asri ve medeni bir millet olduğumuzu ispat eyledik.

Artık millet tamamıla hak ve hâkimiyete malik oldu. Halk, Hükümet serbest serbest çalışacak, memleketimiz pek yakın bir zamanda şenlenecek. Küçük dostlarım; bu sözlerimi iyi dinleyin: Cumhuriyet bir nimettir; bunun kudretini bilin (s:42).

Yazar yukarıdaki ifadelerle Cumhuriyeti daha da yücelterek çocuklara Cumhuriyetin ne kadar önemli bir rejim olduğunu ve adeta halkın kurtuluşunun bu rejimden geçtiğini savunmaktadir.

Üçüncü kısımda "insanın sosyal bir varlık olduğundan mülhem” öğrencilere toplum, toplum hayatı, toplum hayatında üzerimize düşen görevler, öğrencilerin soysal hayatla karşılaşabilecekleri problemler ve bunların çözüm yolları üzerinde durulmuştur. Konular, Cumhuriyetin vatandaşlara sağladığı haklar, hürriyet, eşitlik, dokunulmazlık, tefekkür, konuşma, yayın hakkı, seyahat, sözleşme, çalışma koşulları, mülk edinme, tasarruf, içtima, cemiyet, şirket kurma ve seçme seçilme hak ve hürriyetleridir. Kanun ve bütçe nasıl yapıllır? Şeklinde olup ikinci kısımda olduğu gibi 3 derste işlenmesi öngörülmüştür.

Kitabın üçüncü kısmında topluma dair bilgiler sunulmaktadır. Bu kısımda genel olarak Cumhuriyetin vatandaşlara temin ettiği haklar: hürriyet, eşitlik, vicdan, tefekkür, kelam, yayın, seyahat, sözleşme, çalışma koşulları, mülk edinme, tasarruf, içtima, cemiyet, şirket, seçme seçilme hak ve hürriyetleri, kanun ve bütçenin nasıl yapılması gerektiğine dair konular vardir.

Üçüncü bölümün birinci konusunda Cumhuriyetin bireylere sağladığı haklar ele alınmıştır. Bu haklara özgürlük, eşitlik, dokunulmazlık, çalışma serbestisi, seyahat serbestisi, toplum teşkili ve şirket kurma hakları olarak değinilmiştir. Hürriyetin bazı şekillerini yazar şu şekilde ele almıştır:

Hürriyet, insanın birçok işlerine taalluk edebilir. Şahsımıza, sözümüze, sair harekâtımıza ait hürriyetlerimiz olmasına göre 'Hürriyet' i "şahsa ait hürriyet", "söylemek hürriyeti", "içtima ve iştirak hürriyeti" "vicdan hürriyeti", "mesken hürriyeti" namıyla beş kısma ayırabiliriz (s: 44).

Hürriyeti bu şekilde beş kısma ayıran yazar, bu kısımlarla ilgili bilgiler de sunmuştur. Söz konusu özgürlük türlerine ilişkin açıklayıcı bilgiler vermiştir. Diğer yandan başka haklara da değinmiştir.

Teşkilatı Esasiye Kanunu bize daha birçok haklar, menfaatler temin etmiştir. Mesela (1) Her Türk kanun nazarında müsavidir. Zümre, sınıf. Aile ve fert imtiyazları yoktur. Hiç kimse bize ben senden üstünüm diyemez. Buna hakk1 yoktur. Ve yine haksız muamele yaptığını gördüğümüz zaman hükümet memurlarını amirlerine şikâyet edebilmek hakkımızdır. (1) Malik ve mutasarrıf olduğumuz mal ve mülke başkası tarafından el 
uzatılamaz. (2) hiçbir adamın mektubu açılıp okunamaz. Hiçbir kimse kanunen mensup olduğu mahkemeden başka bir mahkemeye gitmeye cebir olunamaz. Hiçbir kimsenin hükümet tarafindan malı müsadere yani zapt edilemez. Ne derece büyük mücrim olursa olsun bir adama hükümet memurları işkence edemez. Hiçbir fert angarya işlerde kullanılamaz. Bir kanuna müstenit olmaksızın hiçbir kimseden vergi ve resim namıla bir şey alınamaz. Hâlbuki Hükümeti Mutlaka vasıtasıyla idare olunan milletler efradı bu gibi hak ve menfaatlerden mahrumdur. Hürriyetin envainden hiçbirine malik değildir. Buda gösterir ki, Hükümeti Cumhuriyet en iyi usul-1 idaredir (s: 46-47).

Yazar tüm kitap boyunca olduğu gibi yapılan yenilikleri hep eskiyle karşılaştırarak durumu gerekçelendirmeye çalışmaktadır. Yukarıdaki alıntının son cümlelerinde yine aynı şekilde Cumhuriyetin olmadığı devletlerde bireylerin ne kadar çok haktan mahrum olduğunu ifade ederek Cumhuriyet rejimini daha yüceltmeye çalışmıştır. Çocuğun zihninde Cumhuriyet rejiminin en iyi yönetim şekli olduğu fikri uyanıncaya kadar bu tür hatırlatmalar çoğu konuda tekrar tekrar geçmektedir. İdeolojinin yeşerip büyüyebilmesi için bu tür ifadelerin tüm ders kitaplarında olması gayet doğal olarak karşılanabilir. Çünkü yeni kurulan her kurum eskiyle hesaplaşmaktadır.

Seçme ve seçilme hakkına da özellikle değinen yazar bu hakkın Cumhuriyet rejimlerinde en önemli birey hakkı olduğunu vurgulamaktadır. Seçme ve seçilmenin doğru bir şekilde olabilmesi için okumuş ve tahsil sahibi olmak gerektiğini savunan yazar henüz kadınlara bu hakkın verilmeme nedeni olarak onların tahsil ve terbiyelerindeki düşüklügü göstermektedir. Ne zaman ki kadınların tahsil ve terbiye dereceleri artar işte o zaman kadınlara da seçme ve seçilme hakkı verileceğini ifade etmektedir.

Bu bölümde ele alınan konulardan bir diğeri ise meclisin görevleridir. Orhan Fuad, bu görevlere ilişkin birtakım açıklamalar yapmıştır.

Bizim Millet Meclisimizin vazifesi başka devletler meclis-i mebusanlarının vazifesinden bir dereceye kadar farklıdır. Diğer mebusan meclislerinin yalnız [teşri-i] yani kanun yapmak, kanunları tadil ve tefsir eylemek, devletin bütçesini hazırlamak ve tasdik etmek gibi vazifesi varken bizim meclisin bir de [icraî] vazifesi vardır. Yani, mebusların kendi aralarından intihap ettikleri on, on iki kişiden ibaret olan ve umumuna birden [icra vekilleri] heyeti denilen bir meclis çıkan kanunların kararları millet meclisi namına yani ona vekâleten icra ederler (s: 50).

Kitabın dördüncü kısmında devlet yönetimine ilişkin bilgiler sunulmaktadır. Bu kısımda genel olarak Cumhurbaşkanı seçimi, görev ve yetkileri, icra vekilleri heyeti görev, yetki ve sorumlulukları, çeşitli bakanlıklar hakkında bilgiler sunulmaktadır. Yazar söz konusu teknik konularla ilgili Teşkilatı Esasiye kanunundan birçok alıntı yaparak konuyu işlemiş̧tir.

Kitabın son bölümlerinde Cumhuriyet hükümetinin görevleri ve vatandaşların devlete yönelik görevleri ele alınmıştır. Cumhuriyetin görevleri öncelikle güvenlik ve adaleti tesis etme, devleti ve milleti dış tehditlere karşı koruma ve ulaşım ve eğitim işleridir. Hükümetin görevlerinden ilki güvenliği sağlamaktır.

Emniyet ve asayiş, korkusuzluk ve rahatlik demektir. Maksat; ahalinin can ve mal ve namusu ve hukukunun muhafaza altında bulunması, halkın başkaları tarafından bunlara tecavüz edilmeyeceğinden emin olması demektir. Zaten cemaatleri, milletleri [hükümet] 
namıla böyle heyetler teşkiline mecbur eden hal hep bu emniyet ve asayişe nail olmalarını istemelerinin neticesidir. Şu halde hükümetin en birinci ve en büyük vazifesi memlekette emniyet ve asayişi devam ettirmek ve halkı rahatlık ve korkusuzluk içinde yaşatmaktır (s: 62).

$\mathrm{Bu}$ görevi yerine getirebilmek için hükümet ya da devlet mahalle ve köy bekçilerinden, polis ve jandarmadan da faydalanır. Bu noktada yazar her ne pahasına olursa olsun hükümetin güvenlik güçlerinin emniyeti sağlamak için her türlü girişimde bulunabileceği fikrini vermesi ilginçtir. $\mathrm{Bu}$ mesaj çocuklara ne olursa olsun devlete asla karşı gelmemelisiniz diye çevrilebilir.

Hükümetin ikinci görevi adaleti temin ve tesis etmektir. Yazar bu konuda çok net bir şekilde devletin kesinlikle adaleti temin etmesi gerektiğini vurgular. Herkes için eşit şekilde adaleti temin etmeyen bir devletin yaşayamayacağını savunur.

Dünyada zulüm ile hiçbir hükümet yaşayamaz. Her kim olursa olsun - bila istisna mahkeme tarafından gerek şahit gerek maznun sıfatılla davet edilince; hemen bu davete icabet etmeli, mahkemeye gitmelidir.

Kanunun vereceği hükme razı olmalıdır.

Kanun önünde herkesin eşit olduğunu ve kimsenin kanunun verdiği hükme razı olmama gibi bir lüksünün olmadığını yazar dipnotta anlattığı bir olayla çocuklara vermeye çalışır. $\mathrm{Bu}$ olayın öğretmenler tarafından çocuklara anlatılması özellikle ister.

Eski âlimlerden meşhur (Sokrat) bir meseleden dolayı o zamanın kanunları hükmünce idam cezasına mahkûm olmuş idi. Talebesinden ve arkadaşlarından bir kaçı yanına giderek kendisini mahpustan kaçırmak istediklerini söyledikleri zaman (Sokrat) bunlara: vakıan ben masumum. Lakin mademki memleketimin kanunu beni mahkûm ediyor, hâkimlerde bu kanuna göre hareket etmeye, hüküm vermeye mecbur bulunuyor, o halde ortada adaletsizlik yok demektir. Ben verilen cezayı çekeceğim, eğer kaçarsam, asıl cinayeti o zaman işlemiş olurum. Demiş ve kendisine verilen zehri içerek ölmüştür. Bu şayanı dikkat hikâye talebeye anlatılacaktır (s: 64).

Hükümetin üçüncü görevi memleketi her türlü iç ve dış düşmanlardan korumaktır. Dördüncü görev ise eğitim işlerini yürütmektir. Bu konuda yazar öncelikle nicelik anlamında artışa değinmiş ve bu sayede hükümetin ihtiyaç duyduğu memurların yetiştirilebileceğini ileri sürmüştür. Hükümetin beşinci görevi ulaşım işlerini idare etmektir. Hükümetin diğer görevleri, ticareti geliştirmek için girişimlerde bulunmak, halk sağlığına ilişkin çalışmalar yapmak ve halkın işlerini kolaylaştırmaya çalışmak olarak sayılabilir.

$\mathrm{Bu}$ görevlerin yanı sıra vatandaşın da devlete karşı bazı görevleri mevcuttur. Bunlar, yardımlaşma, vatanı sevmek, milli ve dini değerlere saygı göstermek, ecdadın bıraktığı eserlere saygı duymak ve korumak, kamu hizmeti gören kurumlara saygı duymak, askerlik ve vergi olarak sayılabilir. Yazar bu görevlere ilişkin kısa açıklamalarda bulunmuştur.

Kitabın son bölümünde adliye teşkilatıyla ilgili bir ek sunulmuştur. Söz konusu ekte adliye teşkilatının nasıl olduğu anlatılmaktadır.

Memlekette adaletin tevzi ve temini için hükümet her şehirde -lüzumuna göre- bir veya daha ziyade [Mahkemeler] açmıştır. Bu mahkemeler, halkın birbirinden olan şikâyet ve 
davalarını dinleyip hüküm verirler. Bunlar hiçbir tesir altında değildir; Tamamıyla müstakildir. Bunları amiri olan [Adliye vekili] bile bir mahkemenin hükmünü, kararını bozamaz. Teşkilatı Esasiye kanunumuz diyor ki:

Mahkemelerin kararlarını ne Büyük Millet Meclisi, nede icra vekilleri hiçbir vecihle bozamaz, bu karar derhal infaz ve tatbik olunur.

Her mahkemenin bir reisi ve lüzumu kadar azası, müstandıkları ve kâtipleri ve bir müddeiyye-i umumiyesi vardır. Her kim başkasından bir fenalık bir zarar görür ise, hemen -mensup olduğu- mahkemenin müddeiyye-i umumiyesine bir arzuhal vererek kendi hakkının alınmasını ister (s: 73).

Diğer yandan söz konusu ekte mülkiye teşkilatına ilişkin bilgiler de sunulmuştur. $\mathrm{Bu}$ teşkilatı anlatabilmek için yazar örnek bir model vermiş ve bu şekilde konunun daha iyi anlaşılabileceğini düşünmüştür.

$\mathrm{Bu}$ teşkilatın size ruhunu anlatmak için yine mektebimizi misal göstereceğim:

Sizin içinde okuduğunuz mektep adata bir vilayet modelidir. Şöyle ki: eğer ihzari veya ana sınıflarına [nahiye] diyecek olursak diğer sınıfların hepsi birer kaza hükmündedir. Her sınıfin [kazanın] muallimi oranın amiri kaymakamıdır.

$\mathrm{Bu}$ sınıfların yani kazaların heyeti umumiyesi [mektebi] ve bizim teşbihimize göre [vilayet]i teşkil eder ki: bunun müdürü, bu vilayetin amiri, valisidir. Demek vilayetler kazalardan mürekkeptir.

Her kazada bir kaymakam, bir kadı, bir mal müdürü, tahrirat kâtibi; nüfus ve tapu memurları, jandarma bölük kumandanı, polis komiser muavini, bir veya iki mahkeme ile bunların reis ve aza ve müddei umumileri bulunur.

Kaymakam büyük işleri validen, mal müdürü vilayet defterdarından sorup öyle yapar.

Her vilayet merkezinde: bir vali, bir kadı, bir defterdar, bir tahrirat müdürü [mektupçu], nüfus, tapu, sıhhiye, orman ve ziraat, nafıa [ser mühendis] müdürleri, jandarma alay kumandanı, polis merkez memuru veya ser komiser ve bunlara merbut olarak birçok memurlar bulunur.

Her kaza ve vilayet merkezinde kaymakam veya vilayetin reisi altında bir (meclisi idare) bulunur. O kaza veya vilayete ait idari işler, mesela, hükümetin yapacağı mübayia, müzayede, münakasa işleri, maliye dairelerinin hesap cetvellerinin tetkiki ve tasdiki hususları bu meclisten geçer (s: 75-76). 


\section{Sonuç}

Bu çalışmanın amacı; 1924 yılında Muallim Orhan Fuad tarafindan ilk mekteblerin 5. sınıflarında tedrîs edilmek üzere" yazılan "Musâhabât-ı Ahlâkiye ve Malûmât-ı Vataniye 5" adlı vatandaşlık ders kitabını çözümlemek ve çeşitli açılardan değerlendirmektir.

"Musâhabât-ı Ahlâkiye ve Malûmât-l Vataniye 5" kitabının yazarı Muallim Orhan Fuad'dır. Söz konusu kitap Türkiye Cumhuriyeti Maarif Vekâletinin 1340 (1924) senesi ilk mektepler müfredat programına göre okutulmak üzere hazırlanmıștır. Kitap ilk mektepler beşinci sınıflarına mahsus bir Vatandaşlık Bilgisi ders kitabıdır.

Musâhabât-ı Ahlâkiye ve Malûmât-ı Vataniye 5' adlı ders kitabında vurgulanan noktalar ise şu şekildedir.

Vatan kavramı, devletin sınırları yeni belirlendiğinden olsa gerek sınırlar bağlamında ele alınmıştır.

Hükümetin kurulma gerekçesi olarak öncelikle kişinin tabiat içinde yalnız olduğu, daha sonra aile kurduğu ve cemaatleştiği ve büyüyen bu toplum yapısını idare etmek için hükümetin kurulması gerektiği ileri sürülmüştür.

Cumhuriyetin olmadığı devletlerde bireylerin ne kadar çok haktan mahrum olduğunu ifade ederek Cumhuriyet rejimi yüceltilmeye çalışılmaktadır. Çocuğun zihninde Cumhuriyet rejiminin en iyi yönetim şekli olduğu fikri uyanıncaya kadar bu tür hatırlatmalar çoğu konuda tekrar tekrar geçmektedir. İdeolojinin yeşerip büyüyebilmesi için bu tür ifadelerin tüm ders kitaplarında olması gayet doğal olarak karşılanabilir. Çünkü yeni kurulan her kurum eskiyle hesaplaşmaktadır.

Kanun önünde herkesin eşit olduğunu ve kimsenin kanunun verdiği hükme razı olmama gibi bir lüksü yoktur. Bu durumda kanun önünde bireyin boynu kıldan incedir.

Sonuç olarak 5. sınıf vatandaşlık dersi kitabında ele alınan konular genel anlamda devletin tesis edilmesi sürecine odaklanmakta ve ardından rejimin insanlara getirdiği haklara değinmektedir. Öncelikle devletin belli sınırlara sahip bir vatan toprağında kurulması ve bu devleti yönetmek için de bir hükümetin oluşturulmasının gerekçeleri sunulmuştur. Hükümetin gerekliliği konusunda en küçük toplum yapısından en büyüğe doğru gidildikçe böyle bir yapının zorunlu hale geldiği anlatılmıştır. Diğer yandan kurulan devletin rejiminin Cumhuriyet olması, söz konusu devletin çatısı altında yaşayan bireylere diğer rejimlerde olmayan birçok hak ve fayda sağlayacağına değinilmektedir. Bu durumda bireyler Cumhuriyetin en iyi rejim olduğu konusunda ikna edilmeye ve bu yönde düşünmeleri sağlanmaya çalışıldığı söylenebilir. Çünkü kitabın çoğu yerinde rejime ilişkin birçok methiyeler varken diğer rejimler son derece gereksiz ve kötü olarak tanıtılmaktadır. 


\section{Kaynakça}

Çelik, H. (2008). Cumhuriyet dönemi vatandaşlık eğitiminde önemli adımlar. Sakarya Üniversitesi Fen-Edebiyat Dergisi, 10(1), 359-369.

Gürses, F. (2001). Kul Tebaa Yurttaş Cumhuriyet'in Kuruluşundan Günümüze Ders Kitaplarında Yurttaşlık, Ütopya Yayınevi, Ankara.

Karakuş, G. (2018). Cumhuriyet'in Politik Teolojisi, Cedit Neşriyat, Ankara.

İlk Mekteplerin Müfredat Programı (1924). Maarif Vekâleti ilk tedrisat dairesi, İstanbul: Matbaa-1 Amire.

Keskin, Y. (2002).Türkiye'de II. Meşrutiyetten günümüze kadar uygulanmış olan sosyal bilgiler ögretim programlarının analizi ve karşılaştırılması.(Yayınlanmamış Yüksek Lisans Tezi). Marmara Üniversitesi, İstanbul.

Muallim Orhan Fuad. (1924). Musahabat-ı Ahlakiye ve Malumat-ı Vataniye 5, İkdam matbaası, İstanbul.

Doğan, N. (1994). Ders Kitaplarl ve Sosyalleşme, Bağlam Yayınc1lı, İstanbul, 1994.

Parlak, İ. (2005). Kemalist İdeolojide Eğitim Erken Cumhuriyet Dönemi Tarih Ve Yurt Bilgisi Ders Kitapları Üzerine Bir İnceleme. Turhan Kitapevi, Ankara.

Yıldırım, A. ve Şimşek, H. (2011). Sosyal Bilimlerde Nitel Araştırma Yöntemleri. Ankara: Seçkin Yayıncılık. 